\title{
The Effect of Clay Pozzolana-Cement-Composite on the Strength Development of a Hydraulic Backfill*
}

\author{
${ }^{1}$ S. N. Eshun, ${ }^{2}$ S. S. R. Gidigasu, and ${ }^{2}$ S. K. Y. Gawu \\ ECMP GH Ltd, Accra, Ghana \\ ${ }^{1}$ Kwame Nkrumah University of Science and Technology, Kumasi, Ghana
}

Eshun, S. N., Gidigasu, S. S. R., and Gawu, S. K. Y. (2018), "The Effect of Clay Pozzolana-Cement-Composite on the Strength Development of a Hydraulic Backfill”, Ghana Mining Journal, Vol. 18, No. 1, pp. 32 - 38.

\begin{abstract}
The study sought to investigate the potential application of clay pozzolana as a supplement for cement in hydraulic backfill, using classified tailings from AngloGold Ashanti, Obuasi Mine. The percentage of the Portland cement that could be substituted with the clay pozzolana to produce backfill with best strength was determined. $10 \%, 25 \%, 30 \%, 35 \%$ and $40 \%$ of the ordinary Portland cement were replaced with clay pozzolana and then mixed with tailings and water. The slurry produced was cast into cylindrical specimen of $50 \mathrm{~mm}$ diameter by $120 \mathrm{~mm}$ high and tested for compressive strength after curing for 7 , 14, 21, 28 and 56 days. The results indicate that, clay pozzolana-cement composite has potential for application in hydraulic back fill production without increased risk to safety and dilution. It was noted that hydraulic backfill with $10 \%, 25 \%, 30 \%$ and $35 \%$ of the ordinary portland cement replaced with clay pozzolana had strengths greater than those obtained for ordinary portland cement alone. Ten percent (10\%) pozzolana content gave the maximum strength followed by $25 \%$ pozzolana. It is recommended that for safety and economic considerations, the cement content should be replaced by $25 \%$ pozzolana in the production of backfills.
\end{abstract}

Keywords: Hydraulic Backfill, Portland Cement, Clay Pozzolana, Unconfined Compressive Strength

\section{Introduction}

Mine backfill is used in filling mined out areas or voids with for the purposes of either regional stability and or disposal of waste. Backfill has the added benefit of being environmentally friendly by placing waste material underground to prevent environmental hazards. Depending on the function of the backfill, the fill material may require a binding medium or not. The conventional binder is cement. Cement is costly and this cost can increase depending on the required mixed proportions to achieve the designed backfill strength. Where binders are required to meet the backfill designed strength criteria, there is always the desire to reduce cost by examining alternatives to achieve the designed backfill strength with minimum amount of cement by including cement-like materials that are cheaper. In this sense, the waste materials are often placed with very lean cement or other pozzolanic binders to improve the strength properties (Grice, 1998).

The key functions of backfill according to Grice (1998) include: the provision of support to the walls and thus confine the fractured rocks to prevent unravelling; improves the stability of the ground for further ore extraction and also provide a working platform on which men and equipment can operate as in the case of cut-and-fill mining.

Hydraulic backfill was introduced at Anglogold Ashanti (AGA) Obuasi Mine in the early 1990's, and Portland cement has been the only binding material used in the preparation of the backfill. In recent times, the soaring cost of Portland cement has resulted in significant increase in the operational cost of the mine. For instance, in the past ten years, the cost of cement on the Ghanaian market has increased by about $500 \%$ (Adu-Boateng and Bediako, 2006). This coupled with the current downward trajectory of gold prices on the world market, has led to vigorous pursuit of programmes aimed at cutting down cost of operations in the mining industry. One of the very key areas of interest is the search for alternative, cheaper binding material that can supplement or partially substitute cement and at the same time achieve strengths comparable with those achievable with the use of ordinary portland cement alone in the backfilling operations. Fig. 1 presents the consumption and associated cost of cement used in the production of cemented hydraulic backfill at AGA from year 2009 to 2014. It is realized that there is an increase in the amount and cost of cement consumed by the Mine.

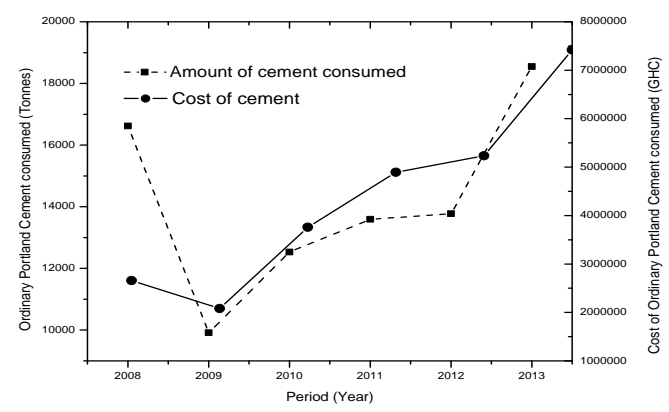

Fig. 1 Cement consumption and associated cost for hydraulic fill at AGA, Obuasi Mine 
Pozzolana or pozzolans is a general term used to describe finely divided siliceous, or siliceous and aluminous, material which by itself possesses little or no cementing value but in the presence of moisture, however, will chemically react with lime at ordinary temperatures to form cementing compounds (Vakili et al., 2013; Anon. 2000a). Natural materials like volcanic ash are pozzolana in their natural state, but materials such as clay, shales, bauxite waste (artificial pozzolana) have to undergo calcination (heat treatment) before they become pozzolanic. Other materials such as fly ash and ground copper furnace are also pozzolanas. According to Thevarasa et al. (1979), some of the advantages of pozzolana cement over ordinary portland cement, are that they:

(i) are cheaper;

(ii) improve plasticity and

(ii) have higher resistance to sulphate attack.

Mertens et al. (2008) also emphasize that pozzolans are known to increase the durability, lower the heat of hydration, increase the resistance to sulphate attack and reduce the energy cost per cement unit. Successful applications of pozzolans in backfills have been reported by for example, Dodd (2000) who estimated that nearly US\$500,000 (representing 18\%) savings was made on pressurized grout remote backfilling projects in the "Abandoned Mine Land" (AML) in North Dakota since 1995 as a result of the use of fly ash. Grice (1998) also reported that Mount Isa Mine in Australia uses ground copper furnace slag to replace half of the cement in backfill to save over 25,000 tonnes of cement annually as a result. Shnorhokian (2009) indicated that, slag produced in northern Ontario is used primarily for mine backfill operations in that region.

Clay pozzolana is a typical artificial pozzolana produced in Ghana on commercial scale by the Pozzolana Ghana Limited through the calcination of clay materials at temperature usually between $700-900{ }^{\circ} \mathrm{C}$. The clay pozzolana is relatively cheap and their production help protect the environment through reduced $\mathrm{CO}_{2}$ emission compared with cement production (Danner et al, 2015). Because of worldwide availability of clays and their low carbon content, these calcined clays provide a forward-looking opportunity for producing sustainable concrete (Beunter and Thienel, 2015). Pozzolana has been found to replace about $30-40 \%$ of cement in concrete works, however, its suitability in hydraulic backfill production in Ghana has not been investigated. This work therefore seeks to investigate the possibility of using clay pozzolana as a partial substitute for cement in hydraulic backfills in Anglogold Ashanti Obuasi Mine.

\section{Resources and Method Used}

\subsection{Materials}

Classified tailings and binding materials namely; ordinary portland cement and clay pozzolana were used in the study. The sources and material characteristics are discussed in the next sections.

\section{Tailings}

Classified tailings were used in the study. The tailings were collected from the AngloGold Ashanti, Obuasi Mine backfill plants situated at the Kwesi Mensah Shaft (KMS) and the George Capendelle Shaft (GCS). The tailings are products of refractory type gold ore, where the gold particles are encapsulated by sulphide minerals, predominantly, arsenopyrite, pyrrhotite and pyrite (Anon, 2005).

The grading of the tailings is shown in Fig. 2. It shows that the particle sizes ranged from $10 \mu \mathrm{m}$ to $300 \mu \mathrm{m}$, with the percentage passing the $11 \mu \mathrm{m}$ sieve being $9.58 \%$ and conform to the requirement proposed by Grice (1998) for hydraulic backfills. This criterion ensures that the acceptable permeability of the placed cemented hydraulic fill is achieved. Thus, not more than $10 \%$ by weight of the tailings should be of particle sizes less than $10 \mu \mathrm{m}$ according to Grice (1998) recommendations.

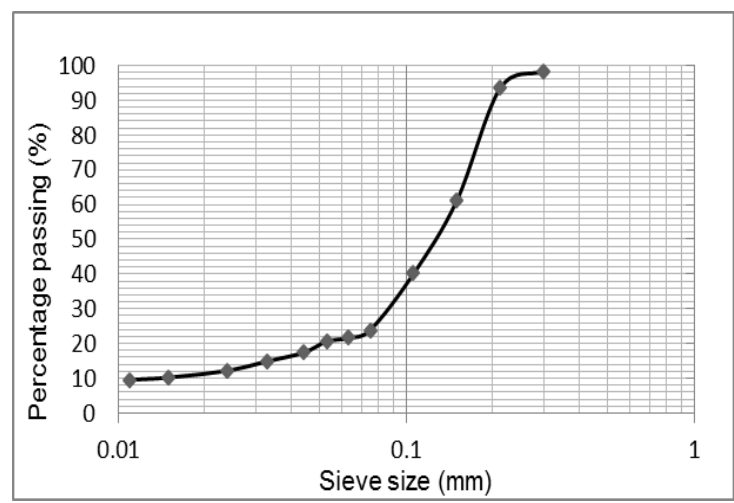

Fig. 2 Grading characteristics of the tailings

\section{Binder Materials}

Ordinary portland cement of class $32.5 \mathrm{~N}$ which conforms to EN 197-1 Standards, produced by Ghana Cement Company Limited (GHACEM) was obtained in $50 \mathrm{~kg}$ bags from the local market. The clay pozzolana on the other hand, manufactured by Pozzolana Ghana Limited was also obtained in $50 \mathrm{~kg}$ bags from the local market. Typical chemical composition of the ordinary Portland cement (OPC) and clay pozzolana are shown in Table 1. 
Table 1 Chemical Composition of the Binder Materials (source: Bediako et al., 2011)

\begin{tabular}{lcc}
\hline \multirow{2}{*}{$\begin{array}{l}\text { Major } \\
\text { Oxides }\end{array}$} & \multicolumn{2}{c}{ Concentration (wt\%) } \\
\cline { 2 - 3 } $\mathrm{SiO}_{2}$ & OPC & Pozzolana \\
\hline $\mathrm{Al}_{2} \mathrm{O}_{3}$ & 5.00 & 61.89 \\
\hline $\mathrm{Fe}_{2} \mathrm{O}_{3}$ & 3.16 & 13.51 \\
\hline $\mathrm{MgO}$ & 1.75 & 5.84 \\
\hline $\mathrm{CaO}$ & 63.03 & 1.74 \\
\hline $\mathrm{Na}_{2} \mathrm{O}$ & 0.20 & 0.21 \\
\hline $\mathrm{K}_{2} \mathrm{O}$ & 0.16 & 0.14 \\
\hline $\mathrm{SO}_{3}$ & 2.80 & 0.14 \\
\hline \multicolumn{3}{c}{${ }^{\#}$ Ordinary Portland Cement }
\end{tabular}

The practice at Anglogold Ashanti Obuasi Mine is that, for a given weight of tailings, $5 \%$ by weight of portland cement is added (Anon, 2012). It is this $5 \%$ cement that the present study replaced portions with pozzolana. Six (6) pozzolana-cement composite binders were prepared by replacing $0 \%$, $10 \%, 25 \%, 30 \%, 35 \%$ and $40 \%$ of portland cement with pozzolana.

\subsection{Methods}

\section{Backfill Sample Preparation}

Four samples of classified tailings collected from the two backfill plants in the mine, were air dried and thoroughly mixed together to obtain a homogenous sample. The classified tailings were then mixed with the pozzolana-cement composite binders. Thirty percent $(30 \%)$ by weight of water was then added and mixed manually using a scoop to obtain a homogenous mixture. The final prepared hydraulic backfills contain $70 \%$ solids and $30 \%$ water.

The hydraulic backfill was then poured into cylindrical moulds made of PVC material with dimensions $50 \mathrm{~mm}$ diameter by $120 \mathrm{~mm}$ high with perforations on them. The ratio of height to diameter was 2.4 which is within the range of 2-2.5 suggested by American Standard for Testing Materials (Tuncay and Hasancebi, 2009) for Unconfined Compressive Strength tests. The perforations were covered with brattice cloth for the purpose of draining the excess water in accordance with the hydraulic backfill practice in the mining industry. The moulds were filled in three layers of approximately equal volumes. The specimens were then stored in a room with relative humidity of approximately $70 \%$ similar to the underground conditions before testing.

Four specimens were prepared for each curing period for each pozzolana-cement composite binder. The curing periods were 7, 14, 21, 28 and
56 days. For each of the pozzolana-cement composite binder used, twenty (20) specimens were produced and the overall number of specimens used in the study was one hundred and twenty (120).

\section{Strength Tests}

Samples produced for each pozzolana-cement composite, cured for 7, 14, 21, 28 and 56 days were tested for their Unconfined Compressive Strengths (UCS) using the ELE compressive strength testing machine. Load was applied gradually to the cylindrical specimen till it failed and the maximum load at failure was recorded. The UCS " $\sigma$ " was then calculated using the relation:

where:

$$
\sigma=\mathrm{F} / \mathrm{A}
$$

$$
\sigma=\mathrm{UCS}
$$

$\mathrm{F}=\mathrm{Load}$ at failure

$\mathrm{A}=$ Cross sectional area of the specimen

The test was conducted on four samples representing a given pozzolana-cement ratio and for each cure period and the average determined.

\section{Results and Discussion}

The practice at Anglogold Ashanti Obuasi Mine is a Method specification, where for a given weight of tailings, $5 \%$ by weight of portland cement is added to produce the hydraulic backfill. In the light of this, the unconfined compressive strength (UCS) obtained for the 5\% Portland cement is used as the standard strength required and the basis for comparison.

The summary of the test results obtained is presented in Table 2.

The variations of unconfined compressive strength values of the samples tested after 7 days, 14 days, 21days, 28 days and 56 days of curing are presented in Fig. 3.

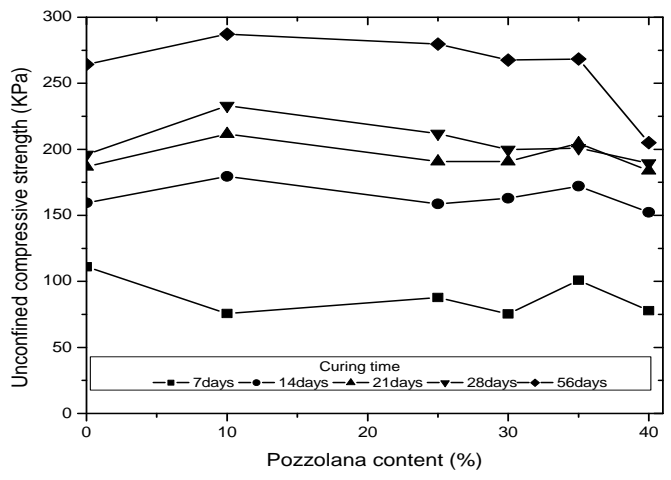

Fig. 3 Variation of UCS with Pozzolana Content 
Table 2 Summary of Results for the Ucs with Curing Time for the Pozzolana Placements

\begin{tabular}{|c|c|c|c|c|c|}
\hline \multirow{2}{*}{ Pozzolana content $(\%)$} & \multicolumn{5}{|c|}{ UCS at specific curing period (KPa) } \\
\cline { 2 - 6 } & $\mathbf{7}$ days & $\mathbf{1 4}$ days & $\mathbf{2 1}$ days & $\mathbf{2 8}$ days & $\mathbf{5 6}$ days \\
\hline $\mathbf{0}$ & 11.09 & 159.45 & 186.86 & 196.09 & 264.35 \\
\hline $\mathbf{1 0}$ & 75.64 & 179.48 & 211.64 & 232.99 & 287.28 \\
\hline $\mathbf{2 5}$ & 87.74 & 158.66 & 190.82 & 211.9 & 279.72 \\
\hline $\mathbf{3 0}$ & 75.38 & 162.88 & 190.82 & 199.78 & 267.62 \\
\hline $\mathbf{3 5}$ & 100.86 & 172.11 & 204.52 & 200.96 & 268.41 \\
\hline $\mathbf{4 0}$ & 77.86 & 152.34 & 183.97 & 189.5 & 204.97 \\
\hline
\end{tabular}

The variations of unconfined compressive strength values of the samples tested after 7 days, 14 days, 21days, 28 days and 56 days of curing are presented in Fig. 3.

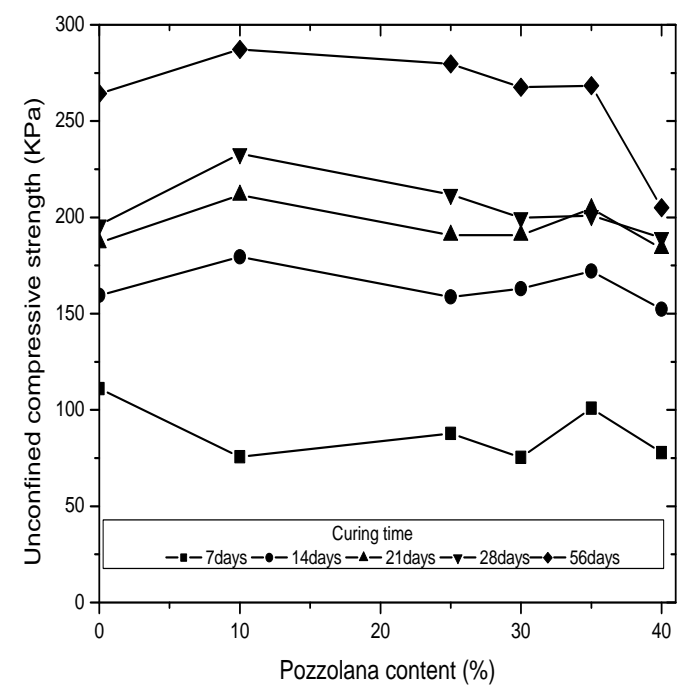

Fig. 3 Variation of UCS with pozzolana content

The strength obtained for the 7 day old specimens OPC alone (without pozzolana) was $111 \mathrm{kPa}$. The strength dropped with the replacement of $10 \%$ of the OPC with clay pozzolana. The $25 \%, 30 \%, 35 \%$ and $40 \%$ cement replacement levels also had strengths lower than the controlled samples. However, the strength properties of the $25 \%, 35 \%$ and $40 \%$ were higher than the $10 \%$ and $30 \%$ replacement levels. The results clearly showed that for the 7 days cured period, the specimens of backfill with Portland cement alone performed better in terms of strength, compared to those specimens with some proportions of the cement replaced with clay pozzolana.

The results of the 14 days cured specimens showed a different pattern from the 7 days. The $10 \%, 30 \%$ and the $35 \%$ cement replacement levels recorded higher strength values than the controlled specimens. The $40 \%$ replacement level recorded the lowest strength value whilst the $10 \%$ replacement level obtained the highest strength.
The results show that, the strength performances by the pozzolana contained backfills are increasing faster with increase in the number of curing days, compared to the controlled specimens. For instance, the respective increases in strengths of the $10 \%, 25 \%, 30 \%, 35 \%$ and $40 \%$ replacement specimens from 7 days to 14 days are $137 \%, 81 \%$, $116 \%, 71 \%$ and $96 \%$ compared to $44 \%$ of the controlled samples.

After curing for 21 days, the test results showed that the $10 \%, 25 \%, 30 \%$ and $35 \%$ replacement levels produced strengths values higher than the controlled samples with the $40 \%$ obtaining strength values lower than the controlled case. The highest strength was obtained by the $10 \%$ replacement level whilst the lowest strength was obtained by the $40 \%$ replacement level. The individual replacement levels gained strengths higher than the controlled case. After 14 days of curing, three replacement levels of $10 \%, 30 \%$ and $35 \%$, showed better strengths. However, after 21 days of curing, four replacement levels, thus, $10 \%, 25 \%, 30 \%$ and $35 \%$, showed better strengths than the controlled.

The $28^{\text {th }}$ day after backfilling is critical to the mining cycle. Usually, mining operations close to hydraulic fill commences after 28 days of curing the hydraulic fill. The results of strength performances by all specimens tested on the 28 day showed that the specimens with $10 \%, 25 \% 30 \%$ and $35 \%$ replacement levels continue to perform better than that of Portland cement alone whilst the $40 \%$ obtained strength values lower than the base case.

The effect of curing time on the unconfined compressive strength of the cemented hydraulic backfills is shown in Fig. 4. It is noted that as the curing period increases, there is a general increase in the normalized UCS of the backfills. 


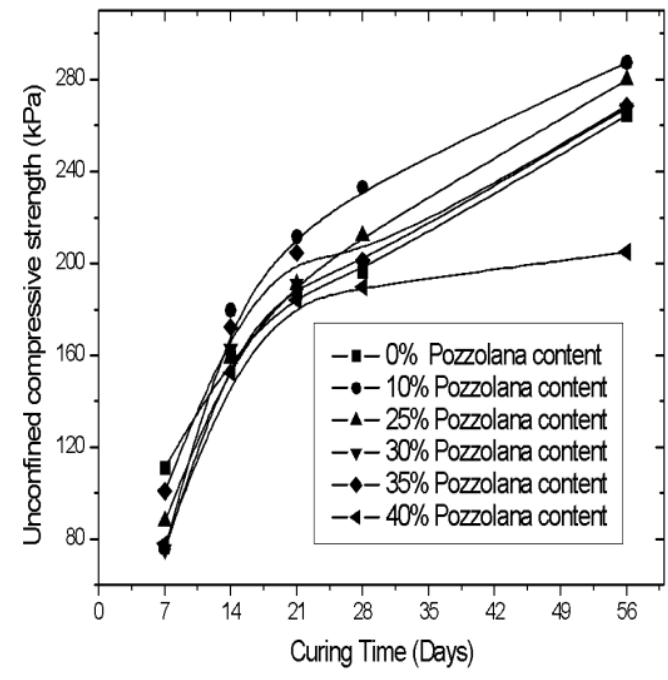

Fig. 4 Variation of UCS with Curing Time of the Backfills

It is observed that the compressive strength values obtained for pozzolana substituted backfills, cured for seven days, were lower than those obtained for ordinary Portland cement backfills for the same period. There were however, rapid strength gains for the pozzolana specimens after the 7 days and this phenomenon has been explained by Yueming et al. (1999) as follows: a) The glassy surface layer of pozzolana which is dense and chemically stable and prevents the interior constituents which are porous and amorphous and therefore more reactive, from taking part in the pozzolanic reaction; b) The silica-alumina chain of pozzolanas is firm and must be broken if activity is to be enhanced.

Masniyom (2009) also attributes the slow reaction of pozzolans at the early stages to the fact that pozzolans have to wait for Portland cements to hydrate and release lime into solution before they begin reaction. Generally, strength increases with curing period as expected. Ostnor (2007) also observed the slow hardening rate of pozzolans at start but indicates the long term strength can be substantial. $\mathrm{Pu}$ (1999) explained why pozzolana containing cement can produce better strength in the long term. According to him, the free lime produced during hydration of cement has low strength and stability. The lime also provides avenue for attack by sulphate solutions, leading to lower strength and less durability of cement paste and concrete. With the addition of pozzolans, the active silica and alumina present in the pozzolans will have secondary reactions with the free lime, removing it from solution and producing stable calcium hydrosilicates and calcium hydroaluminates.

The tailings used for the study had higher sulphate concentration compared with the upper limits set by the Americans Society for Testing and Materials (Anon. 2000b) and European Standard (Anon. 2002) as seen in Table 3.

Table 3 Sulphate Concentration in the Tailings

\begin{tabular}{|l|c|c|}
\hline \multirow{2}{*}{$\begin{array}{l}\text { Obuasi } \\
\text { Tailings }\end{array}$} & \multicolumn{2}{|c|}{ Standard Limits } \\
\cline { 2 - 3 } & ASTM C94 & EN 1008 \\
\hline 3500 ppm & $<3000 p p m$ & $<2000 p p m$ \\
\hline
\end{tabular}

\section{Cost benefit Analyses}

Results of the study showed that, 10\%, 25\%, 30\% and $35 \%$ of ordinary Portland cement could be replaced with clay pozzolana to produce backfills of strengths comparable to ordinary Portland cement. Table 4 presents the savings that could be made by AngloGold Ashanti Mine, if it incorporates pozzolana in the hydraulic backfill. This analysis was based on data for year 2013. It is noted that as pozzolana content increases there is an increase in the savings. If $10 \%$ and $25 \%$ pozzolana contents were used giving that they gave the maximum UCS strengths, then the annual saving would be US\$ 57,867.00 and US\$ $144,667.00$ corresponding to $3 \%$ and $7.5 \%$ respectively.

Table 4 Savings on Cost of Backfill Production Utilising Portland Cement+ Pozzolana

\begin{tabular}{|c|c|c|c|c|c|c|c|}
\hline \multirow{2}{*}{$\begin{array}{l}\text { Pozzolana } \\
\text { content }(\%)\end{array}$} & Pozzolana & Cement & Pozzolana & Cement & \multirow{2}{*}{$\begin{array}{l}\text { Total Cost } \\
\text { (\$) }\end{array}$} & \multirow{2}{*}{$\begin{array}{l}\text { Savings } \\
\text { (\$) }\end{array}$} & \multirow{2}{*}{$\begin{array}{c}\text { *Savings } \\
(\%)\end{array}$} \\
\hline & \multicolumn{2}{|c|}{ Quantity (tonnes) } & \multicolumn{2}{|c|}{ Cost (\$) } & & & \\
\hline 0 & 18,547 & 0 & 0 & $1,928,888$ & $1,928,888$ & 0 & 0 \\
\hline 10 & 16,692 & 1,855 & 135,022 & $1,735,999$ & $1,871,021$ & 57,867 & 3 \\
\hline 25 & 13,910 & 4,637 & 337,555 & $1,784,221$ & $2,121,777$ & 144,667 & 8 \\
\hline 30 & 12,983 & 5,564 & 405,066 & $1,755,288$ & $2,160,355$ & 173,600 & 9 \\
\hline 35 & 12,056 & 6,491 & 472,578 & $1,726,355$ & $2,198,932$ & 202,533 & 11 \\
\hline
\end{tabular}




\section{Conclusions}

Based on the study the following conclusions were made:

(i) Clay pozzolana has the potential to replace portions of the ordinary portland cement to produce cemented hydraulic backfills of strengths comparable or even higher than those obtainable for Portland cement alone.

(ii) $10 \%, 25 \%, 30 \%$ and $35 \%$ ordinary portland cement can be replaced with clay pozzolana to produce backfills comparable to ordinary portland cement, whereas $40 \%$ pozzolana produced lower strengths with respect to ordinary portland cement alone, with curing time. $10 \%$ pozzolana gave the maximum compressive strength with curing time.

(iii) If $10 \%$ and $25 \%$ pozzolana contents were used in the production of the hydraulic backfills (giving that they gave the maximum UCS strengths), then the annual saving would be US\$57,867.00 and US\$ $144,667.00$ corresponding to $3 \%$ and $7.5 \%$ respectively.

From the conclusions, it is recommended that for safety and economic considerations, the cement content should be replaced by $25 \%$ pozzolana in the production of backfills

\section{References}

Adu-Boateng, A. O. and Bediako, M. (2006), "The use of Clay as Pozzolana for Building Purposes in Ghana", Building Integration Solutions, pp. $1-10$.

Anon. (2000a), "Standard Specification for Fly Ash and Raw or Calcined Natural Pozzolana for use as a Mineral Admixture in Portland Cement Concrete", Annual Book of ASTM Standards: Part 14-C 618, ASTM, Philadelphia, USA, pp. 355-358.

Anon. (2000b), "Standard Specification for Ready Mixed Concrete", ASTM Standards C 94, West Conshohocken, USA, $10 \mathrm{pp}$

Anon. (2002), "Mixing water for concrete, Specification for sampling, testing and assessing suitability of water including water recovered from concrete industry as water for concrete" The European Standards, EN 1008, CEM, Brussels, 22 pp.

Anon. (2005), "Metallurgical Services Manual", AngloGold Ashanti Obuasi Mine Internal operations Document, pp. 1-29.

Anon. (2012), "Backfill Operations Manual" AngloGold Ashanti, Obuasi Mine Internal Operations Document, pp. 1-16.
Bediako, M. A., Adjaottor, A. A. and Gawu, S. K. Y. (2011), "Selected Mechanical Properties of Mortar used for Masonry Incorporating Artificial Pozzolana". Proceedings of the 6th International Structural Engineering and Construction Conference, Zurich, Switzerland, pp. 569-574.

Beutner, N. and Thienel. K. Ch., (2015), "Properties of Calcined Lais Delta Clay Technological Effects, Physical Characteristics and Reactivity in Cement", $I^{\text {st }}$ International Conference on Calcined Clays for Sustainable Concrete, Scrivener, K. and Favier, A. (eds.), Lausanne, Switzerland, pp. 43-50.

Danner, T., Justnes, H, Norden, G. and Østnor, T. (2015), "Feasibility of Calcined Marl as an alternative Pozzolanic Material". $1^{\text {st }}$ International Conference on Calcined Clays for Sustainable Concrete, Scrivener, K. and Favier, A. (eds.), Lausanne, Switzerland, pp. 67-73.

Dodd, W. E. (2000), "Fly Ash use in Pressurized Grout Remote Backfilling of Abandoned Underground Mines in North Dakota", Workshop on Abandoned Underground Mine, Kansas Department of Transport, Kansas City, USA, pp. 1-5.

Grice, T. (1998), "Underground Mining with Backfill". The $2^{\text {nd }}$ Annual Summit-Mine tailing disposal systems, Brisbane, Australia, pp. 1-14.

Masniyom, M. (2009), "Systematic Selection and Application of Backfill in Underground Mines". $\mathrm{PhD}$ thesis, Geotechnical and Civil, Technical University Bergakadimie Freiberg, Germany, $168 \mathrm{pp}$.

Mertens, G., Snellings, R., Van Balen, K., BicerSimsir, B., Verlooy, P. and Elsen, J. (2008), "Pozzolanic Reactions of Common Natural Zeolites with Lime and Parameters Affecting their Reactivity", Cement and Concrete Research, Vol. 39, No. 3, pp. 233-240.

Østnor, T. (2007), "Alternative Pozzolans as Supplementary Cementitious Material in Concrete", Advanced Cementing Materials, SINTEF Report, Trondheim, Norway, $25 \mathrm{pp}$.

$\mathrm{Pu}, \mathrm{X}$. (1999), "Investigation on pozzolanic effect of mineral additives in cement and concrete by specific strength index". Cement and Concrete Research, Vol. 29, pp. 951-955.

Shnorhokian, S. (2009), "Development of Quantitative Accelerated Sulphate Attack Test for Mine Backfill". PhD Thesis, McGill University, Montreal, Canada, 217 pp.

Thevarasa, A., Perampalam, V. and Selvaratnam, M. (1979), "Some Studies on Pozzolanic Cement”, Sri Lanka Journal of Science Council, Vol.7, No.1, pp. 57-63.

Tuncay, E. and Hasancebi, N. (2009), "The effect of length to diameter ratio of test specimens on the uniaxial compressive strength of rock". 
Bulletin of Engineering Geology and the Environment, Vol 68, pp. 491-497.

Vakili, A. H., Selamat, M. R. and Moayedi, H. (2013), "Effects of Using Pozzolan and Portland Cement in the Treatment of Dispersive Clay", The Scientific World Journal, http://dx.doi.org/10.1155/2013/547615, 10pp.

Yuemin, F., Suhong, Y., Zhiyun, W. and Jingyu, Z. (1999), "Activation of fly ash and its effects on cement" properties. Cement and Concrete Research, Vol. 29, No. 4, pp. 467-472.

\section{Authors}

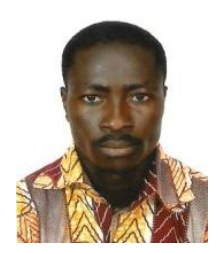

Samuel N. Eshun is the Operations Director of ECMP $(\mathrm{GH})$ Ltd. He holds MSc in Environmental Resource Management from the Kwame Nkrumah University of Science and Technology, Kumasi-Ghana. He also has a BSc in Natural Resources Management and HND in Civil Engineering from the Universities of Ghana and Cape Coast Technical University respectively. He was formerly, Backfill Engineer at the AngloGold Ashanti Obuasi Mine from 2012 to 2015 . His research interests are in the areas of application of admixtures in mine paste and hydraulic fills production; Mine waste disposal and water quality management.

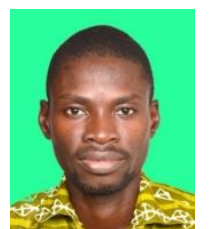

Solomon S. R. Gidigasu is an Assistant Lecturer and a $\mathrm{PhD}$ student at the Department of Geological Engineering, Kwame Nkrumah University of Science and Technology (KNUST), Ghana. He holds Master of Philosophy and Bachelor of Science degrees in Geological Engineering from KNUST. His areas of research are Engineering Geology and Geomechanics.

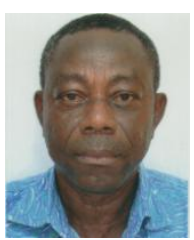

Simon K.Y. Gawu is an Associate Professor at the Department of Geological Engineering at the Kwame Nkrumah University of Science and Technology, Kumasi, Ghana. His main research interest is in Geomaterials Characterization and Engineering. He uses various disciplines, for example, unsaturated soil mechanics, geochemistry, mineralogy, rheology, geo-mechanics etc in characterizing these materials. 